\title{
Fusarium circinatum and pitch canker of Pinus in Colombia
}

\author{
E. T. Steenkamp • C. A. Rodas • M. Kvas • \\ M. J. Wingfield
}

Received: 29 September 2011 / Accepted: 4 January 2012 /Published online: 8 February 2012

(C) Australasian Plant Pathology Society Inc. 2012

\begin{abstract}
Pitch canker, caused by the ascomycete fungus Fusarium circinatum, infects a wide range of Pinus species. The pathogen has a global distribution and limits plantation productivity wherever susceptible Pinus species are commercially cultivated. During 2005-2007, symptoms typical of those associated with $F$. circinatum were observed in Colombia on nursery seedlings of $P$. maximinoi, P. tecunumanii and P. patula, as well as established P. patula and $P$. kesiya trees in plantations. Symptoms on seedlings included collar and root disease while shoot dieback and resinous stem cankers were found on trees in plantations. The aim of this study was to isolate and identify the causal agent of these symptoms and to evaluate the relative tolerance of various families of Pinus species commonly grown in Colombia. By making use of morphology and DNA-based methods, as well as pathogenicity tests on P. patula seedlings, it was possible to show that the symptoms observed in the nursery and field were caused by F. circinatum. Furthermore, the results of pathogenicity tests with two virulent isolates of the pathogen indicated that $P$. tecunumanii from low-elevation sources and $P$. maximinoi are significantly more tolerant to infection by $F$. circinatum than $P$. tecunumanii from high-elevation sources and $P$. patula. These results show that there is substantial opportunity to avoid
\end{abstract}

\footnotetext{
E. T. Steenkamp $(\bowtie) \cdot$ M. Kvas $\cdot$ M. J. Wingfield

Department of Microbiology and Plant Pathology,

Tree Protection Co-operative Programme, Forestry and Agricultural

Biotechnology Institute (FABI), University of Pretoria,

Pretoria 0002, South Africa

e-mail: emma.steenkamp@fabi.up.ac.za

C. A. Rodas

Smurfit Kappa Cartón de Colombia, Investigación Forestal,

Kilometro 15 Autopista Cali - Yumbo,

Cali, Valle, Colombia
}

losses due to infection by F. circinatum through deployment of resistant planting stock.

Keywords Fusarium circinatum . Pitch canker. Pathogenicity $\cdot$ DNA-based diagnostics $\cdot$ Pinus species

\section{Introduction}

Pitch canker of pine is caused by the ascomycete fungus Fusarium circinatum (teleomorph $=$ Gibberella circinata) (Nirenberg and O'Donnell 1998; Wingfield et al. 2008). Usually, the first symptoms of the disease are wilting and discolouration of needles, followed by dieback due to the development of resinous cankers at the sites of infection (reviewed by Wingfield et al. 2008). Because F. circinatum can infect vegetative and reproductive structures of susceptible hosts of all ages, the pathogen can affect roots, shoots, stems, flowers, cones, seed and seedlings. In the case of seedlings, the pathogen causes root disease and girdling of root collars.

Fusarium circinatum has a global distribution and is capable of infecting a wide range of Pinus species, as well as Pseudotsuga menziesii (Wingfield et al. 2008). In its suggested center of origin (i.e., Mexico and neighboring Central America) (Wikler and Gordon 2000), the pathogen is known to be associated with native species such as $P$. douglasiana and $P$. durangensis, as well as planted $P$. radiata and P. halepensis (Guerra-Santos 1999; Santos and Tovar 1991). In the southeastern United States, P. elliottii and P. taeda have been affected most severely (Hepting and Roth 1946), and in California pitch canker has devastated natural and planted stands of $P$. radiata (Gordon et al. 2001). The disease also occurs on native Pinus species in Haiti (Hepting and Roth 1953), Japan (Kobayashi and Muramoto 1989), Korea (Woo et al. 2010), Spain (Landeras et al. 2005) 
and Italy (Carlucci et al. 2007). In Spain, South Africa, and Korea pitch canker occurs in planted stands of important nonnative forestry species (Coutinho et al. 2007; Iturritxa et al. 2011; Landeras et al. 2005; Lee et al. 2000; Woo et al. 2010). In Spain, South Africa, Chile, Portugal and Uruguay, $F$. circinatum further also limits seedling production in commercial forestry nurseries (Alonso and Bettucci 2009; Bragança et al. 2009; Landeras et al. 2005; Wingfield et al. 2002a, b).
In Colombia, symptoms resembling those caused by $F$. circinatum were observed on four Pinus species important for commercial forestry in that country (Fig. 1). In November 2005 , seedlings of $P$. patula displaying symptoms such as wilt, shoot dieback and roots with small resin-soaked necrotic lesions were observed in a nursery located in Valle del Cauca. In this nursery, similar symptoms also were observed subsequently on seedlings of $P$. tecunumanii and $P$. maximinoi. In
Fig. 1 Symptoms associated with the pitch canker fungus, $F$. circinatum, which were observed on Pinus species in Colombia. A: stem discoloration on a four month-old seedling of P. patula. B: a seedling of $P$. tecunumanii with wilting and dieback symptoms. C: constricted root collar on a $P$. maximinoi seedling. D: copious resin bleeding from an infection site on the root collar of a $P$. maximinoi seedling. E: "flagging" of branches on 11-year old P. patula. F: pitch-soaked, resinous wood on the stem of an 18-month old $P$. kesiya tree
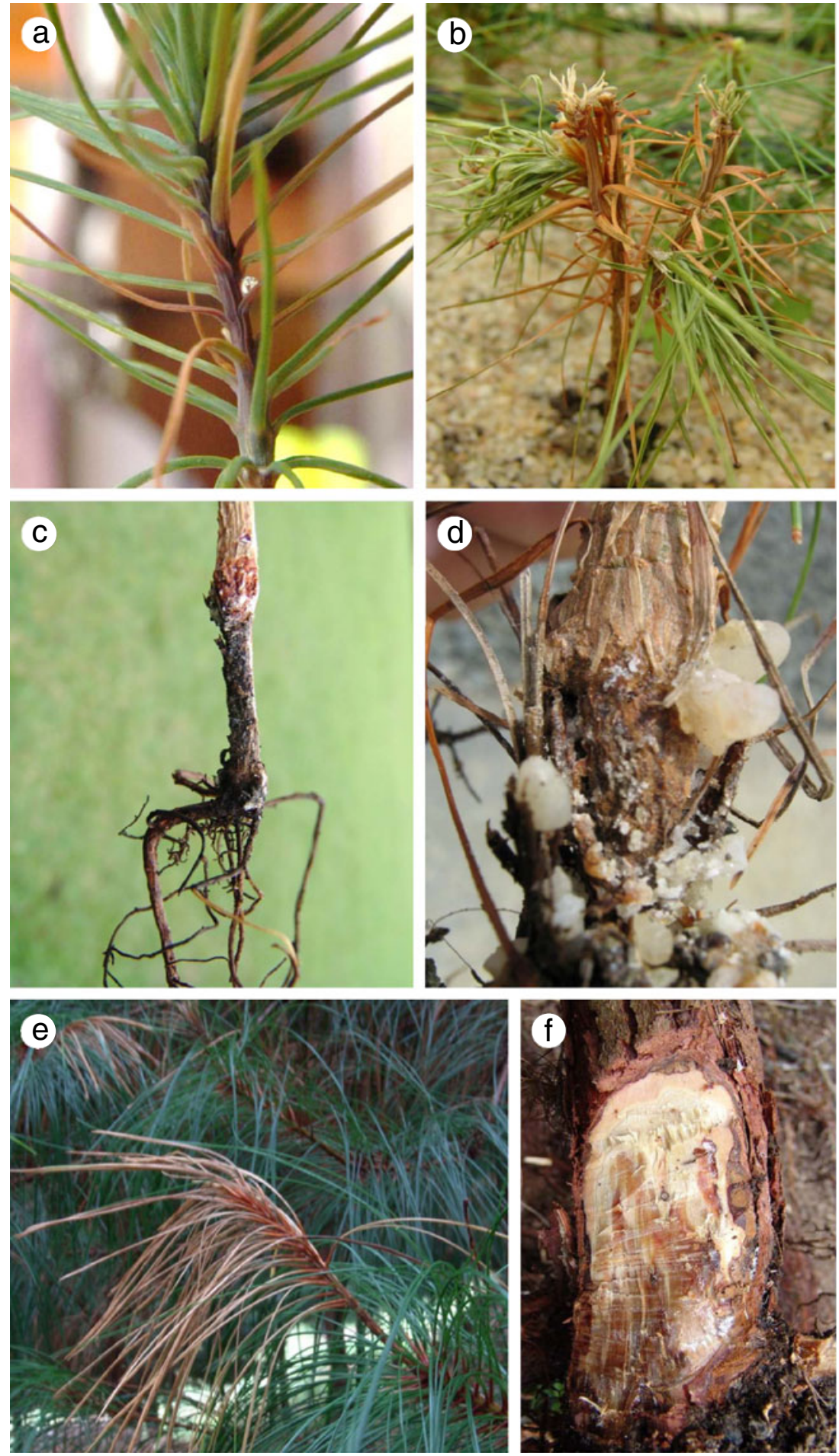
March 2006, symptoms typical of pitch canker (e.g., shoot and twig dieback, and the presence of resinous cankers on trunks and branches) were observed on 11-year old P. patula trees near Santa Rosa (Risaralda). During 2006 and 2007, shoot dieback was also observed on established $P$. patula and $P$. kesiya trees in plantations in Valle del Cauca and Antioquia, respectively.

The association of F. circinatum with Pinus species is almost always correlated with significant economic losses (Dwinell et al. 1985). This could be due to reduction in tree growth (Arvanitis et al. 1984; Bethune and Hepting 1963) or failure of seedlings to establish in the field (Crous 2005; Mitchell et al. 2011). An increase in the mortality of nursery seedlings (Wingfield et al. 1999) and trees in natural stands or plantations (Blakeslee and Oak 1979) can also result in dramatic losses. Therefore, if the pathogen occurs on commercially important Pinus species in Colombia, similar losses could occur. Approximately $35 \%$ of the total forestry plantation area in Colombia is planted to Pinus species (IDEAM 2009) and the export of timber and related products contributes considerably to the country's gross domestic product (Mendell et al. 2006). Understanding the potential involvement of the pitch canker pathogen in contributing to the symptoms observed on the four non-native Pinus species is thus important; not only from a disease management point of view, but also in considering the long-term consequences of pitch canker in Colombia.

The aims of this study were firstly to isolate and identify the fungal species associated with the diseased $P$. kesiya, $P$. maximinoi, P. tecunumanii and P. patula during 2005-2007. For this purpose we employed methodologies based on fungal morphology and DNA sequence data. A second goal was to determine the pathogenicity of the isolated fungi on commercially important families of $P$. patula, P. maximinoi and P. tecunumanii.

\section{Materials and methods}

Fungal isolates

The Fusarium isolates used in this study were obtained from diseased plants in four different geographic locations in Colombia (Table 1). These locations have cool temperate climates with daily temperatures of $17-22^{\circ} \mathrm{C}$ and annual precipitation of $1125-2688 \mathrm{~mm}$. Diseased tissues of threeto four-month old P. patula, P. tecunumanii and P. maximinoi seedlings were collected from a nursery near Restrepo in Valle del Cauca. Samples were collected from 11-year old P. patula trees near Santa Rosa de Cabal (Risaralda) and from six-month old P. patula trees near Santa Rosa de Osos (Antioquia). Diseased tissue samples were also obtained from 18-month old P. kesiya plants in the Cumbre area (Valle del Cauca).

For the isolation of fungi, diseased tissue samples were surface-sterilized for 1 minute in a commercial bleach solution containing $1.5 \%$ sodium hypochlorite and then rinsed well with sterile distilled water. Small pieces of tissue, cut from the edges of lesions, were placed directly onto medium containing Potato Dextrose Agar (PDA, $20 \mathrm{gl}^{-1}$ PDA [Merck, Germany], $5 \mathrm{gl}^{-1}$ agar [Merck]), and incubated for 7 days at $22^{\circ} \mathrm{C}$. Fungi resembling those in the genus Fusarium were transferred to Petri plates containing PDA. After another round of incubation at $22^{\circ} \mathrm{C}$ for 7 days, the fungi on these plates were used to prepare pure cultures by transferring single germinating conidia to fresh PDA medium. All cultures were deposited in and can be obtained from the culture collection of the Tree Protection Cooperative Programme, Forestry and Agricultural Biotechnology Institute, University of Pretoria, Pretoria, South Africa.

Table 1 Host, geographic origin and sequence accession numbers for the isolates of $F$. circinatum used in this study

\begin{tabular}{|c|c|c|c|c|}
\hline Isolate $^{\mathrm{a}}$ & Pinus host & Area in Colombia & $\begin{array}{l}\text { GPS coordinates, rainfall, and } \\
\text { average temperature }^{b}\end{array}$ & $\begin{array}{l}\text { Sequence accession } \\
\text { numbers }\end{array}$ \\
\hline CMW 21140 & P. patula & Restrepo (Valle del Cauca) & $1450\left(76^{\circ} 29^{\prime} 49^{\prime \prime} \mathrm{W} 3^{\circ} 51^{\prime} 45^{\prime \prime} \mathrm{N}\right) 1067,20$ & JN642099, JN642106 \\
\hline CMW 21144 & P. patula & Restrepo (Valle del Cauca) & $1450\left(76^{\circ} 29^{\prime} 49^{\prime \prime} \mathrm{W} 3^{\circ} 51^{\prime} 45^{\prime \prime} \mathrm{N}\right) 1067,20$ & JN642100, JN642107 \\
\hline CMW 25509 & P. maximinoi & Restrepo (Valle del Cauca) & $1450\left(76^{\circ} 29^{\prime} 49^{\prime \prime} \mathrm{W} 3^{\circ} 51^{\prime} 45^{\prime \prime} \mathrm{N}\right) 1067,20$ & JN642101, JN642108 \\
\hline CMW 25510 & P. tecunumanii & Restrepo (Valle del Cauca) & $1450\left(76^{\circ} 29^{\prime} 49^{\prime \prime} \mathrm{W} 3^{\circ} 51^{\prime} 45^{\prime \prime} \mathrm{N}\right) 1067,20$ & JN642102, JN642109 \\
\hline CMW 25518 & P. kesiya & Cumbre (Valle del Cauca) & $1525\left(76^{\circ} 31^{\prime} 46^{\prime \prime} \mathrm{W}, 3^{\circ} 42^{\prime} 10^{\prime \prime} \mathrm{N}\right) 1108,21$ & JN642103, JN642110 \\
\hline CMW 25519 & P. patula & Santa Rosa de Cabal (Risaralda) & $1971\left(75^{\circ} 36^{\prime} 21^{\prime \prime} \mathrm{W}, 4^{\circ} 49^{\prime} 18^{\prime \prime} \mathrm{N}\right) 2688,17$ & JN642104, JN642111 \\
\hline CMW 25520 & P. patula & Santa Rosa de Osos (Antioquia) & $2480\left(75^{\circ} 26^{\prime} 30^{\prime \prime} \mathrm{W} 6^{\circ} 52^{\prime} 4^{\prime \prime} \mathrm{N}\right) 2600,17$ & JN642105, JN642112 \\
\hline
\end{tabular}

${ }^{a} \mathrm{CMW}=$ Culture Collection, Tree Protection Co-operative Programme, Forestry and Agricultural Biotechnology Institute, University of Pretoria, South Africa. CMW 21140 and CMW 21144 were isolated by MJ Wingfield, while CMW 25509, CMW 25510, CMW 25518, CMW 25519 and CMW 25520 were isolated by CA Rodas

${ }^{\mathrm{b}}$ GPS $=$ Global positioning System. Elevation in meters above sea level is followed by location coordinates in parentheses, average annual rainfall (mm/year) and average temperature $\left({ }^{\circ} \mathrm{C}\right)$

${ }^{\mathrm{c}}$ GenBank $^{\circledR}$ accession numbers are provided for each isolate in the order TEF, $\beta$-tubulin 
Identification of fungi

All isolates were grown on synthetic low nutrient agar (Nirenberg 1976) and carnation leaf agar (Fisher et al. 1982) for identifications using morphology. Following incubation for about 10 days at $25^{\circ} \mathrm{C}$ under near ultraviolet light, the fungi were examined microscopically. We specifically considered the diagnostic characters proposed by Nirenberg and O'Donnell (1998), Britz et al. (2002) and Leslie and Summerell (2006).

For identifications based on DNA sequence information, total DNA was extracted from seven-day old PDA cultures (Steenkamp et al. 1999). These DNA extracts were used as templates in PCRs with primers EF1 and EF2 (O'Donnell et al. 1998b) and primers T1 and T2 (O'Donnell and Cigelnik 1997) to amplify diagnostic portions of the genes encoding translation elongation factor 1-alpha (TEF) and $\beta$-tubulin, respectively. These primers were also used for sequencing the respective fragments. All PCRs and sequencing reactions were performed as described previously (Kvas et al. 2008) by making use of a GeneAmp ${ }^{\circledR}$ PCR system 9700 (Applied Biosystems, Foster City, California) and a 3730 DNA Analyzer (Applied Biosystems).

Raw sequence files were analysed with Chromas Lite 2.0 (Technelysium, Australia) and BioEdit version 7.0.5.2 (Hall 1999). Sequences were compared to those in GenBank ${ }^{\circledR}$ (Benson et al. 2011) using nucleotide BLAST searches. The TEF sequences were also compared to those in the Fusarium Identification Database (Geiser et al. 2004; http://isolate.fusariumdb.org/index.php). Multiple alignments and phylogenies based on Bayesian inference and maximum likelihood were constructed using previously described procedures (Kvas et al. 2008) and, respectively, MAFFT v6 (http://align.bmr.kyushu-u.ac.jp/mafft/online/ server/) (Katoh et al. 2002), MrBayes v3.1.2 (Ronquist and Heuelsenbeck, 2003) and PHYML v2.2.4 (Guindon and Gascuel 2003).

\section{Pathogenicity tests}

All pathogenicity tests with $F$. circinatum were performed on eight- or nine-month old Pinus seedlings in a greenhouse at Restrepo in Colombia. The plants were grown in plastic containers and maintained at approximately $22^{\circ} \mathrm{C}$ under natural light at the Rancho Grande Nursery in Restrepo. Before inoculation, the trees were allowed to acclimatize in the greenhouse for 4 weeks. Conidial suspensions $(50000$ conidia $\mathrm{ml}^{-1}$ sterile water) were prepared from eight-day old fungal cultures grown on PDA. These suspensions were used as inoculum, where $100 \mu \mathrm{l}$ of the suspension were placed onto wounds left after removal of terminal buds. For the control treatments, inoculations were performed with $100 \mu \mathrm{l}$ of sterile water. To prevent desiccation of the inoculum, inoculated plants were covered with plastic bags for $12 \mathrm{~h}$, after which the bags were removed.

Results of pathogenicity tests were evaluated 16 weeks after inoculation by measuring the length of the internal lesions that developed. These lesions were exposed by scraping away the bark at the point of inoculation with a sterile scalpel. To confirm that the lesions were caused by the isolates used for inoculation, re-isolations were made from three randomly selected plants per isolate and identifications were made as described above. Statistical analyses were performed with the SAS/STAT software (SAS Institute 2009). Analysis of Variance (ANOVA) was used to determine significant differences among treatments and their interactions, while the Sidak method was used for comparing treatment differences (SAS Institute 2009).

Two separate sets of pathogenicity tests were performed. The first set of tests was conducted with seven isolates of $F$. circinatum that originated from four Pinus species in Colombia (Table 1). These were used in pathogenicity tests on nine-month old $P$. patula plants, where 20 trees were inoculated with each isolate or sterile water for the control inoculations. The entire trial was repeated three times, giving a total of 480 trees inoculated. The second set of tests was conducted with two isolates (CMW 21140, CMW 21144) of $F$. circinatum that were selected based on their high level of pathogenicity in the first trial. The two isolates were used to inoculate eight-month old seedlings of five different Pinus families, which were selected to represent the main species planted in the region. The five families included P. tecunumanii (PTECCATA) originating from a high elevation source (Cauca, Colombia) and P. tecunumanii (PTECSUIZ) originating from a low elevation source (Valle del Cauca), as well as two families of $P$. maximinoi (PM1564CA and PM1517CA) and a family of $P$. patula (PPATPNEG). For this set of tests, ten plants were inoculated with each isolate and sterile water was again used for the control inoculations. The entire trial was repeated three times, giving a total of 450 trees inoculated.

\section{Results}

Identification of fungi

Isolates resembling members of the genus Fusarium were obtained from diseased trees and seedlings of P. patula, $P$. maximinoi, $P$. tecunumanii and $P$. kesiya collected at the four different locations in Colombia (Table 1). Microscopic examination revealed that they generally produced sterile coiled hyphae, lunate macroconidia, branched conidiophores and polyphiallides with two to five conidiogenous openings. These traits are characteristic of $F$. circinatum (Britz et al. 2002; Leslie and Summerell 2006; Nirenberg and O’Donnell 1998). 
The TEF sequences for the seven isolates from Colombia were identical and comparison with those in the Fusarium Identification Database and GenBank ${ }^{\circledR}$, showed that they were very similar to known isolates of the pitch canker fungus (see Table 1 for GenBank ${ }^{\circledR}$ assession numbers). For example, their sequences contained only eight nucleotides that were different from that of isolate NRRL 25331, the ex-holotype of F. circinatum (Nirenberg and O'Donnell 1998), and one nucleotide different from those of the $F$. circinatum mating-type tester strains MRC 7488 and MRC 6123 (Britz et al. 1999). With regards to their $\beta$-tubulin sequences, the Colombian isolates were identical to one another and to the three isolates mentioned above (see Table 1 for GenBank ${ }^{\circledR}$ assession numbers). Phylogenetic analysis of the data further showed that the isolates from Colombia form part of a well-supported group that also include isolates of $F$. circinatum from South Africa, Japan and USA (Fig. 2). These results thus confirmed that the fungi isolated from the diseased P. patula, P. maximinoi, $P$. tecunumanii and $P$. kesiya plants in Colombia represent the pitch canker pathogen, F. circinatum.

Pathogenicity tests

Four of the $F$. circinatum isolates (CMW 21140, CMW 21144, CMW 25510 and CMW 25520) tested for pathogenicity on nine-month old $P$. patula plants produced lesions that were significantly larger $(P \leq 0.0001)$ than those observed for the control treatments (Table 2). The longest lesions were produced by isolates CMW 21144, CMW 25520 and CMW 21140, which were all obtained from $P$. patula. The mean lesion lengths caused by isolates CMW 25509 (isolated from P. maximinoi), CMW 25518 (isolated from P. kesiya) and CMW 25519 (isolated from P. patula) were not significantly different from those of the control treatment. However, F. circinatum was successfully re-
Fig. 2 A maximum likelihood phylogeny inferred from combined TEF and $\beta$-tubulin sequence data for the so-called "American Clade" of the Gibberella fujikuroi complex of which $F$. circinatum is a member (O'Donnell et al. 1998a; Geiser et al. 2005). Bootstrap support values $\geq 75 \%$ and Bayesian posterior probabilities $\geq 0.95$ are indicated at the branches in the order maximum likelihood/ Bayesian inference, and lack of support is indicated with "-". The tree is rooted with the Fusarium species in the so-called "African Clade" of the G. fujikuroi complex

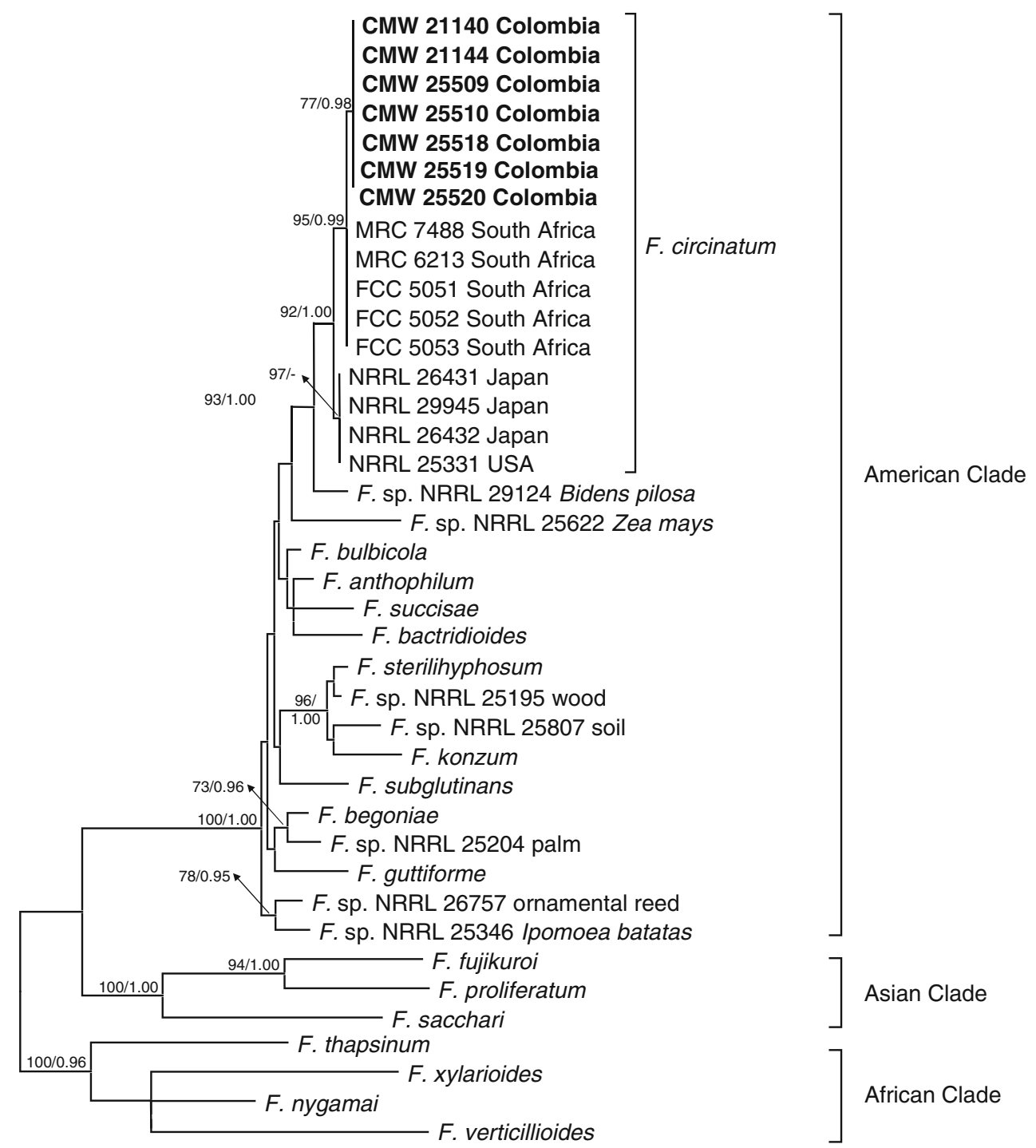


Table 2 The results of a pathogenicity study with Colombian isolates of $F$. circinatum on nine-month old $P$. patula plants

\begin{tabular}{lll}
\hline Isolate/treatment & Mean lesion length in $\mathrm{mm}^{\mathrm{a}}$ & Standard error \\
\hline CMW 21140 & $7.77(\mathrm{a})$ & 1.26 \\
CMW 21144 & $9.23(\mathrm{a})$ & 1.29 \\
CMW 25509 & $0.91(\mathrm{~b})$ & 0.59 \\
CMW 25510 & $6.03(\mathrm{a})$ & 1.07 \\
CMW 25518 & $5.36(\mathrm{ab})$ & 1.07 \\
CMW 25519 & $4.78(\mathrm{ab})$ & 0.96 \\
CMW 25520 & $7.91(\mathrm{a})$ & 1.22 \\
Control & $1.86(\mathrm{~b})$ & 0.91
\end{tabular}

${ }^{\text {a }}$ Data represent means of the 60 measurements obtained for each isolate, because similar results were obtained for all the repeats of the pathogenicity test. A one-way analysis of variance (ANOVA) indicated a significant treatment effect, where the observed $F$-value is 7.517 and the significance probability associated with the $F$-statistic is $<0.0001$. Individual means were compared and grouped using the Sidak method and a confidence level of $95 \%$. Means that were not significantly different are indicated in parentheses by the same letter

isolated from all of the examined inoculated plants and not from the control plants. This confirmed Koch's postulates showing that the observed symptoms were caused by the pitch canker pathogen.

Isolates CMW 21144 and CMW 21140 were used to evaluate resistance to $F$. circinatum in five pine families. All inoculations with the two isolates produced lesions that were significantly $(P \leq 0.0001)$ larger than the control treatments. The results of the two-way ANOVA indicated that the response variable, lesion length, is strongly dependent on the genotypes of the fungus and the plant, as well as the interaction between these two factors (Table 3). Although these data indicate that typical genotype-by-genotype interactions underlie resistance of Pinus to the pitch canker fungus (Lambrechts et al. 2006; Gordon and Leveau 2010), both of the $F$. circinatum isolates produced significantly larger lesions on P. patula and P. tecunumanii

Table 3 Results of a two-way analysis of variance (ANOVA) of the pathogenicity of two isolates of $F$. circinatum on five Pinus families ${ }^{\mathrm{a}}$

\begin{tabular}{llllll}
\hline $\begin{array}{l}\text { Source of } \\
\text { variation }\end{array}$ & $\begin{array}{l}\text { Degrees of } \\
\text { freedom }\end{array}$ & $\begin{array}{l}\text { Sum of } \\
\text { squares }\end{array}$ & $\begin{array}{l}\text { Mean } \\
\text { squares }\end{array}$ & $F$ statistic & $P$-value \\
\hline $\begin{array}{l}\text { Isolates } \\
\text { Pine families }\end{array}$ & 2 & 2421.85 & 1210.92 & 62.31 & $<0.0001$ \\
$\begin{array}{l}\text { Isolates X pine } \\
\text { families }\end{array}$ & 8 & 6824.97 & 1706.24 & 87.80 & $<0.0001$ \\
$\begin{array}{l}\text { Error } \\
\text { Int }\end{array}$ & 423 & 3692.34 & 461.54 & 23.75 & $<0.0001$ \\
& & 8220.48 & 19.43 & & \\
\hline
\end{tabular}

${ }^{\text {a }}$ Lesion length was analyzed as the response variable with fungal genotype (i.e., isolate of F. circinatum) and plant genotype (i.e., pine family) as two explanatory factors (both treated as fixed effects). The analysis was performed with SAS and employed type III sums of squares (SAS Institute 2009)
(PTECCATA) than on the other P. tecunumanii (PTECCSUIZ) family and the two P. maximinoi families (Table 4).

\section{Discussion}

In this study, we show conclusively that the disease symptoms observed in Colombia on the roots of P. patula, P. tecunumanii and $P$. maximinoi seedlings, as well as on the branches and trunks of P. kesiya and P. patula in established plantations were caused by the pitch canker fungus. Together with this first report from Colombia, pitch canker and its causal fungus, F. circinatum is now known from three South American countries. In 2002, F. circinatum-associated root disease was detected in both containerized and open rooted clonal hedges of $P$. radiata in a commercial nursery in Chile (Wingfield et al. 2002b). More recently in 2009, the pathogen was reported from seedlings of $P$. taeda in Uruguay (Alonso and Bettucci, 2009). However, in contrast to the situation in Colombia, $F$. circinatum appear to be limited to pine seedling nurseries in Chile and Uruguay and typical pitch canker symptoms have not yet been observed in plantation trees in these countries.

Apart from the nursery seedlings affected by $F$. circinatum, symptoms were also observed on 18-month old $P$. kesiya and six-month old $P$. patula plants. In South Africa and Chile, mortality of, respectively, $P$. patula and $P$. radiata plants in these age classes has also been observed to be due to infection by F. circinatum (Crous 2005; Mitchell et al. 2004; Wingfield et al. 2008). In P. patula, mortality usually starts 3 to 6 months post-planting and can persist for up to 2 years (Crous, 2005). Such infections are believed to originate from infected but asymptomatic plants (Storer et al. 1998) in the nursery. Although it is not known how and why the pathogen switches from a latent phase to actively infecting the host plant, the stresses associated with outplanting

Table 4 Results of a pathogenicity study with two Colombian isolates of F. circinatum (CMW 21140 and CMW 21144) on eight-month old Pinus seedlings

\begin{tabular}{lll}
\hline Pinus family & \multicolumn{2}{l}{$\begin{array}{l}\text { Mean lesion length in mm } \\
\text { (Standard error) }\end{array}$} \\
\cline { 2 - 3 } & CMW 21140 & CMW21144 \\
\hline P. patula (PPATPNEG) & $17.40(1.41) \mathrm{c}$ & $12.11(1.91) \mathrm{b}$ \\
P. tecunumanii (PTECCATA) & $9.12(0.99) \mathrm{b}$ & $8.48(1.51) \mathrm{b}$ \\
P. tecunumanii (PTECSUIZ) & $0.90(0.77) \mathrm{a}$ & $0.65(0.57) \mathrm{a}$ \\
P. maximinoi (PM1564CA) & $0.57(0.11) \mathrm{a}$ & $0.00(0.00) \mathrm{a}$ \\
P. maximinoi (PM1517CA) & $0.00(0.00) \mathrm{a}$ & $0.15(0.10) \mathrm{a}$
\end{tabular}

${ }^{a}$ The data represent means of the 30 measurements obtained for each isolate, as similar results were obtained for all three repeats of the pathogenicity test. Individual means were compared and grouped using the Sidak method and a confidence level of $95 \%$. Means that were not significantly different are indicated by the same letter 
and post-planting establishment in the field are probably important (Wingfield et al. 2008). Therefore, some of the disease symptoms observed in Colombia could reflect a similar problem with seedling establishment after planting in the field, which is associated with significant economic losses in South Africa (Mitchell et al. 2011). Extensive surveys are required to fully quantify the extent to which F. circinatum-associated post-planting establishment problems in pine plantations might impact Colombian forestry.

The fact that pitch canker occurred on 11-year old $P$. patula trees in one area in Risaralda, suggests the pitch canker pathogen in Colombia is not only a problem of seedlings and their establishment in the field, but also of older established plantation trees. A similar situation occurs in South Africa where the pitch canker pathogen was first discovered on $P$. patula seedlings in a single nursery in 1990, after which it spread to almost all commercial forestry nurseries (Wingfield et al. 2008). It was only recently, in 2005 , that an outbreak of the disease occurred on five- and nine-year old P. radiata (Coutinho et al. 2007). Although it remains unclear why pitch canker in established plantations emerged only 15 years after the pathogen was first recorded in South Africa, the involvement of the non-native deodar weevil (Pissodes nemorensis) has been suggested (Coutinho et al. 2007). It is possible that the disease in Risaralda on $P$. patula trees could also be via infection of wounds made by pine-feeding insects that have been introduced to that region. No such insects or insect damage were observed but future studies should seek to determine the origin of infection courts on plantation trees in this region. Such information, together with knowledge regarding ecological and environmental factors that might facilitate infection (Wingfield et al. 2008) would be invaluable for preventing or managing this and other field outbreaks of pitch canker in Colombia.

The results of the pathogenicity tests on nine-month old $P$. patula seedlings suggested a significant level of genetic diversity within the Colombian population of the pathogen. Although only seven isolates of $F$. circinatum were examined in this study, the isolates varied widely in terms of the length of lesions that they induced on the seedlings (Table 2). An analysis of more extensive collections of isolates and the application of markers such as microsatellites or vegetative compatibility groups will provide a much clearer view of the population biology and origin of $F$. circinatum in Colombia. Such studies have shown, for example, that $F$. circinatum in California was introduced from the southeastern United States (Wikler and Gordon 2000) and that pitch canker in northern Spain is probably due to one or a few introductions (Iturritxa et al. 2011). A detailed understanding of the population biology of $F$. circinatum in Colombia should, therefore, reveal whether the pathogen originated from contaminated seed that was imported from Mexico or
Central America, as have been shown for the pathogen in South Africa (Britz et al. 2001; Wikler and Gordon 2000), or from some other source.

Of the five pine species that were evaluated in this study, $P$. tecunumanii originating from high-elevation sources and $P$. patula were most susceptible to infection by the pitch canker fungus. In contrast, very small lesions were induced by the pathogen on the two $P$. maximinoi families and the $P$. tecunumanii family originating from low-elevation sources (Table 4). These findings are in agreement with what has been demonstrated previously (Hodge and Dvorak 2000, 2007). The apparent resistance of species such as $P$. maximinoi, $P$. tecunumanii and $P$. oocarpa to pitch canker has boosted their popularity in tropical and subtropical regions. Furthermore, the results of a recent study that modeled the potential impact of climate change on P. patula and $P$. tecunumanii, suggest that provenances of $P$. tecunumanii from low-elevation sources in Central America would be most productive in the future (Leibing et al. 2009). The latter species, together with $P$. maximinoi, therefore, are expected to become increasingly important for commercial forestry in Colombia.

The results of previous pitch canker resistance screening studies and climate change predictions should be interpreted with care. Although the results of greenhouse trials are generally predictive of host resistance under field conditions (Gordon et al. 1998a, b), the possibility that different virulence and pathogenicity factors might be operational in the greenhouse and field (Matheson et al. 2006) is rarely considered. Also, in most cases, the relative resistance or tolerance of a Pinus species or family to F. circinatum is based on tests with a limited number of isolates. However, one genotype of the pathogen will not necessarily express similar levels of pathogenicity in different Pinus species or genotypes, which is also evident from our results (Table 3) and those reported previously (Hodge and Dvorak 2007). This is because virulence is dependent on genetic factors determined by both the host and the pathogen (e.g., Gordon and Leveau 2010; Lambrechts et al. 2006; Thompson and Burdon 1992). Furthermore, the climate change models suggested for $P$. patula and $P$. tecunumanii (Leibing et al. 2009) did not take into account the pitch canker fungus and its inherent genetic diversity or its ability to change with time. Like its plant host, F. circinatum will likely adapt to climate change, but predictions regarding such adaptations are confounded by a general lack of understanding of the pathogen's ecology and biology. Therefore, as is the case wherever Pinus species are commercially cultivated, the continued and sustainable use of pine in Colombia will be dependent on a multi-faceted and integrated approach. This will need to consider not only the host and its associated diversity and adaptability, but also the biology of the pathogen and environmental factors involved in the disease. 
Acknowledgements We thank Smurfit Kappa Cartón de Colombia, the members of the Tree Protection Cooperative Programme (TPCP) and University of Pretoria, as well as the National Research Foundation (NRF) and the THRIP support programme of the Department of Trade and Industry in South Africa for financial support. We also thank Liliana Perafan and Mauricio Zapata of Smurfit Kappa Cartón de Colombia for their assistance with statistical analyses.

\section{References}

Alonso R, Bettucci L (2009) First report of the pitch canker fungus Fusarium circinatum affecting Pinus taeda seedlings in Uruguay. Australas Plant Dis Notes 4:91-92

Arvanitis LG, Godbee JF Jr, Porta I (1984) Pitch canker impact on volume growth: a case study in slash pine plantations. South J Appl For 8:43-47

Blakeslee GM, Oak SW (1979) Significant mortality associated with pitch canker infection of slash pine in Florida. Plant Dis Rep 63:1023-1025

Benson DA, Karsch-Mizrachi I, Lipman DJ, Ostell J, Sayers EW (2011) GenBank. Nucleic Acids Res 39(Database issue):D32-D37

Bethune JE, Hepting GH (1963) Pitch canker damage to south Florida slash pine. J For 61:517-522

Bragança H, Diogo E, Moniz F, Amaro P (2009) First report of pitch canker on pines caused by Fusarium circinatum in Portugal. Plant Dis 93:1079

Britz H, Coutinho TA, Wingfield MJ, Marasas WFO, Gordon TR, Leslie JF (1999) Fusarium subglutinans f.sp. pini represents a distinct mating population in the Gibberella fujikuroi species complex. Appl Environ Microbiol 65:1198-1201

Britz H, Coutinho TA, Gordon TR, Wingfield MJ (2001) Characterisation of the pitch canker fungus, Fusarium circinatum, from Mexico. S Afr J Bot 67:609-614

Britz H, Coutinho TA, Wingfield MJ, Marasas WFO (2002) Validation of the description of Gibberella circinata and morphological differentiation of the anamorph Fusarium circinatum. Sydowia 54:9-22

Carlucci A, Colatruglio L, Frisullo S (2007) First report of pitch canker caused by Fusarium circinatum on Pinus halepensis and P. pinea in Apulia (Southern Italy). Plant Dis 91:1683

Coutinho TA, Steenkamp ET, Mongwaketsi K, Wilmot M, Wingfield MJ (2007) First outbreak of pitch canker in a South African pine plantation. Australas Plant Pathol 36:256-261

Crous JW (2005) Post establishment survival of Pinus patula in Mpumalanga, 1 year after planting. South Afr For J 205:3-11

Dwinell LD, Barrows-Broaddus J, Kuhlman EG (1985) Pitch canker: a disease complex of southern pines. Plant Dis 69:270-276

Fisher NL, Burgess LW, Toussoun TA, Nelson PE (1982) Carnation leaves as a substrate and for preserving cultures of Fusarium species. Phytopathology 72:151-153

Geiser DM, Jiménez-Gasco MM, Kang S, Makalowski I, Veeraraghavan N, Ward TJ, Zhang N, Kuldau GA, O'Donnell K (2004) FUSARIUM-ID v. 1.0: a DNA sequence database for identifying Fusarium. Eur J Plant Pathol 110:473-479

Geiser DM, Ivey ML, Hakiza G, Juba JH, Miller SA (2005) Gibberella xylarioides (anamorph: Fusarium xylarioides), a causative agent of coffee wilt disease in Africa, is a previously unrecognized member of the G. fujikuroi complex. Mycologia 97:191-201

Gordon TR, Okamoto D, Storer AJ, Wood DL (1998a) Susceptibility of five landscape pines to pitch canker disease, caused by Fusarium subglutinans $\mathrm{f}$. sp. pini. HortSci 33:868-871

Gordon TR, Wikler KR, Clark SL, Okamoto D, Storer AJ, Bonello P (1998b) Resistance to pitch canker disease, caused by Fusarium subglutinans $\mathrm{f}$. sp. pini, in Monterey pine (Pinus radiata). Plant Pathol 47:706-711

Gordon TR, Storer AJ, Wood DL (2001) The pitch canker epidemic in California. Plant Dis 85:1128-1139

Gordon TR, Leveau JHJ (2010) Plant pathology: a story about biology. Annu Rev Phytopathol 48:292-309

Guindon S, Gascuel O (2003) PHYML - A simple, fast, and accurate algorithm to estimate large phylogenies by maximum likelihood. Syst Biol 52:696-704

Guerra-Santos JJ (1999) Pitch canker on Monterey pine in Mexico. In 'Current and potential impacts of pitch canker in radiata pine. Proceedings of the IMPACT Monterey workshop, California, USA, 30 November to 3 December 1998'. Forestry and Forest Products No.112. (Eds ME Devey, AC Matheson, TR Gordon) pp 58-61. (CSIRO: Canberra)

Hall TA (1999) BioEdit: a user-friendly biological sequence alignment editor and analysis program for Windows 95/98/NT. Nucleic Acids Symp Ser 41:95-98

Hepting GH, Roth ER (1946) Pitch canker, a new disease of some southern pines. J For 44:724-744

Hepting GH, Roth ER (1953) Host relations and spread of the pine pitch canker disease. Phytopathology 43:475

Hodge GR, Dvorak WS (2000) Differential responses of Central American and Mexican pine species and Pinus radiata to infection by the pitch canker fungus. New Forests 19:241-258

Hodge GR, Dvorak WS (2007) Variation in pitch canker resistance among provenances of Pinus patula and Pinus tecunumanii from Mexico and Central America. New Forests 33:193-206

IDEAM (Instituto de Hidrologia, Meteorologia y Estudios Ambientales) (2009) Informe Anual sobre el estado del medio ambiente y los recursos naturales renovables en Colombia: Bosques-2009, p 236

Iturritxa E, Ganley RJ, Wright J, Heppe E, Steenkamp ET, Gordon TR, Wingfield MJ (2011) A genetically homogenous population of Fusarium circinatum causes pitch canker of Pinus radiata in the Basque Country, Spain. Fungal Biol 115:288-295

Katoh K, Misawa K, Kuma K, Miyata T (2002) MAFFT: a novel method for rapid multiple sequence alignment based on fast Fourier transform. Nucleic Acids Res 30:3059-3066

Kobayashi T, Muramoto M (1989) Pitch canker of Pinus luchuensis, a new disease of Japanese forests. Forest Pests 40:169-173

Kvas M, Steenkamp ET, Al Dawi AO, Deadman ML, Al Jahwari AA, Marasas WFO, Wingfield BD, Ploetz RC, Wingfield MJ (2008) Fusarium mangiferae associated with mango malformation in the Sultanate of Oman. Eur J Plant Pathol 121 (1):95-199

Lambrechts L, Fellous S, Koella JC (2006) Coevolutionary interactions between host and parasite genotypes. Trends Parasitol 22:12-16

Landeras E, García P, Fernández Y, Braña M, Fernández-Alonso O, Méndez-Lodos S, Pérez-Sierra A, Léon M, Abad-Campos P, Berbegal M, Berltrán R, Gárcia-Jiménez J, Armengol J (2005) Outbreak of pitch canker caused by Fusarium circinatum on Pinus spp. in northern Spain. Plant Dis 89:1015

Leibing C, van Zonneveld M, Jarvis A, Dvorak W (2009) Adaptation of tropical and subtropical pine plantation to climate change: realignment of Pinus patula and Pinus tecunumanii genotypes to 2020 planting site climates. Scand J For Res 24:483-493

Lee JK, Lee SH, Yang SI, Lee YW (2000) First report of pitch canker disease on Pinus rigida in Korea. Plant Pathol J 16:52-54

Leslie JF, Summerell BA (2006) The Fusarium laboratory manual. Blackwell Professional, Ames, Iowa

Matheson AC, Devey ME, Gordon TR, Werner W, Vogler DR, Balocchi C, Carson MJ (2006) Heritability of response to inoculation by pine pitch canker of seedlings of radiata pine. Aust For 69:101-106 
Mendell BC, De La Torre R, Sydor T (2006) Timberland investments in South America: a profile of Colombia. Timber Mart-South Market News Quarterly 3rd Quarter, pp 13-14

Mitchell RG, Zwolinski J, Jones NB, Coutinho TA (2004) The effect of applying prophylactic measures on the post-planting survival of Pinus patula in South Africa. South Afr For J 200:51-59

Mitchell RG, Steenkamp ET, Coutinho TA, Wingfield MJ (2011) The pitch canker fungus, Fusarium circinatum: implications for South African forestry. Southern Forests 73:1-13

Nirenberg HI (1976) Untersuchungen über die morphologische und biologische Differenzierung in der Fusarium-Sektion Liseola. Mitteilungen aus der Biologischen Bundesanstalt für Landund Forstwirtschaft 169:1-117

Nirenberg HI, O'Donnell K (1998) New Fusarium species and combinations within the Gibberella fujikuroi species complex. Mycologia 90:434-458

O’Donnell K, Cigelnik E (1997) Two divergent intragenomic rDNA ITS2 types within a monophyletic lineage of the fungus Fusarium are nonorthologous. Mol Phylogenet Evol 7:103-116

O’Donnell K, Cigelnik E, Nirenberg HI (1998a) Molecular systematics and phylogeography of the Gibberella fujikuroi species complex. Mycologia 90:465-493

O’Donnell K, Kistler HC, Cigelnik E, Ploetz RC (1998b) Multiple evolutionary origins of the fungus causing Panama disease of banana: concordant evidence from the nuclear and mitochondrial gene genealogies. Proc Natl Acad Sci USA 95:2044-2049

Ronquist F, Heuelsenbeck JP (2003) MrBayes: Bayesian phylogenetic inference under mixed models. Bioinformatics 19:1572-1574

Santos JJG, Tovar DB (1991) Algunos aspectos sobre el cancro resinoso de los pinos. In 'VI Simposio Nacional Sobre Parasitologia orestal, October 1991'. p 31. (Unidad de Xcongresos del Colegio de Postgraduados Montecillos: Edo, Mexico)

SAS Institute (2009) SAS System for Windows Version 9.2. SAS Institute Inc., Cary, NC, USA
Steenkamp ET, Wingfield BD, Coutinho TA, Wingfield MJ, Marasas WFO (1999) Differentiation of Fusarium subglutinans $f$. sp. pini by histone gene sequence data. Appl Environ Microbiol 65:34013406

Storer AJ, Gordon TR, Clark SL (1998) Association of the pitch canker fungus, Fusarium subglutinans f. sp. pini with Monterey pine seeds, and seedlings in California. Plant Pathol 47:649-656

Thompson JN, Burdon JJ (1992) Gene-for-gene coevolution between plants and parasites. Nature 360:121-126

Wikler KR, Gordon TR (2000) An initial assessment of genetic relationships among populations of Fusarium circinatum in different parts of the world. Can J Bot 78:709-717

Wingfield MJ, Wingfield BD, Coutinho TA, Viljoen A, Britz H, Steenkamp ET (1999) Pitch canker: a South African perspective. In 'Current and potential impacts of pitch canker in radiata pine. Proceedings of the IMPACT Monterey workshop, California, USA, 30 November to 3 December 1998'. (Eds ME Devey, AC Matheson, TR Gordon) pp 62-69. (CSIRO Forestry and Forest Products No. 112: Canberra)

Wingfield MJ, Coutinho TA, Roux J, Wingfield BD (2002a) The future of exotic plantation forestry in the tropics and southern hemisphere: lessons from pitch canker. South Afr For J 195:79-82

Wingfield MJ, Jacobs A, Coutinho TA, Ahumada R, Wingfield BD (2002b) First report of the pitch canker fungus, Fusarium circinatum, on pines in Chile. Plant Pathol 51:397

Wingfield MJ, Hammerbacher A, Ganley RJ, Steenkamp ET, Gordon TR, Wingfield BD, Coutinho TA (2008) Pitch canker caused by Fusarium circinatum - a growing threat to the pine plantations and forests worldwide. Australas Plant Pathol 37:319-334

Woo K-S, Yoon J-H, Han S-U, Kim C-S (2010) Assessment of pathogenic variation against pitch canker pathogen, Fusarium circinatum in Pinus thunbergii and responses of natural selection Pinus $\mathrm{x}$ rigitaeda to branch inoculation in a seed orchard. Plant Pathol J 26:299-305 